\title{
BCOR mutation and TLS-ERG expression in acute myeloid leukemia with monoclonal immunoglobulinemia
}

This article was published in the following Dove Press journal: OncoTargets and Therapy

\section{Jingxia Jin \\ Shuna Luo \\ XingNong Ye \\ Jian Huang}

Department of Hematology, The Fourth Affiliated Hospital, Zhejiang University School of Medicine, Yiwu, Zhejiang 322000, People's Republic of China
Correspondence: Jian Huang Department of Hematology, The Fourth Affiliated Hospital, Zhejiang University School of Medicine, NI Shangcheng Road, Yiwu, Zhejiang 322000, People's Republic of China

Tel +86 I $886796 \quad 032$

Fax +8657989935555

Email househuang@zju.edu.cn

\begin{abstract}
Acute myeloid leukemia (AML) originates from the abnormal clonal proliferation of myeloblasts. Immunoglobulin is secreted by B cells. AML with monoclonal antibody often indicates a poor prognosis. Here we report a case of BCOR mutation and TLS-ERG expression in AML with monoclonal immunoglobulinemia. After chemotherapy, the patient achieved bone marrow complete remission. BCOR mutation and TLS-ERG fusion gene in patient's bone marrow were not detected, at the same time, peripheral blood monoclonal immunoglobulin also disappeared. BCOR mutation or $T L S-E R G$ fusion gene expression is associated with poor prognosis, AML with monoclonal immunoglobulin may have the same prognostic significance.
\end{abstract}

Keywords: acute myeloid leukemia, bone marrow, monoclonal immunoglobulin, TLS-ERG, BCOR

\section{Introduction}

Acute myeloid leukemia (AML) originates from the abnormal clonal proliferation of myeloblasts which often combined with clinical symptoms such as infection, fever, hemorrhage and anemia. Cytogenetic and molecular abnormalities are frequent in AML patients. To date, the driver genes for leukemia remain largely undiscovered. Monoclonal immunoglobulinemia is a group of diseases caused by excessive proliferation of plasma cells or immunoglobulin-producing lymphoid plasma cells and B lymphocytes. It can develop into malignant plasma cell disease. Herein, we report an AML patient was concomitant with monoclonal immunoglobulinemia, the patient was also accompanied by BCOR mutation and TLS-ERG fusion gene.

\section{Patients and methods}

\section{Patients}

A 55-year-old female was admitted to the hospital due to "repeated edema of both lower limbs for 3 weeks, and white blood cells count increase for 1 day" on August 20, 2018. Before admission, she did not receive any treatment. On admission, physical examination: except for edema of both lower limbs, all other signs were negative, peripheral blood counts: PLT $142 \times 10^{9} / \mathrm{L}$, Hb $77 \mathrm{~g} / \mathrm{L}$, and WBC $35.2 \times 10^{9} / \mathrm{L}$.

Bone marrow examination showed the mononuclear cell system proliferated actively, and the primitive monocytes accounted for $86 \%$. Cell morphology 
suggested M5b (Figure 1A). Bone marrow pathology: acute non-lymphocytic leukemia, with MPO (positive), CD34 (positive), CD117 (positive). Fusion gene screening in bone marrow revealed that TLS-ERG expression, all screened genes are shown in Table 1 . Immunophenotype of bone marrow cell: Abnormal myeloid primitive cells accounted for $96.39 \%$ of the nuclear cells, express CD33, CD13, CD123, CD34, CD9, MPO (Figure 1D). Medium express CD117, CD38, CD11b, CD64, CD56. Weak express HLA-DR. Karyotype analysis of bone marrow cells: $46, \mathrm{XX},+1$, $\operatorname{der}(16) \operatorname{der}(1: 16)(\mathrm{q} 10 ; \mathrm{p} 10) \mathrm{t}(16 ; 21)(\mathrm{p} 11 ; \mathrm{q} 22), \quad \operatorname{der}(21) \mathrm{t}$
A
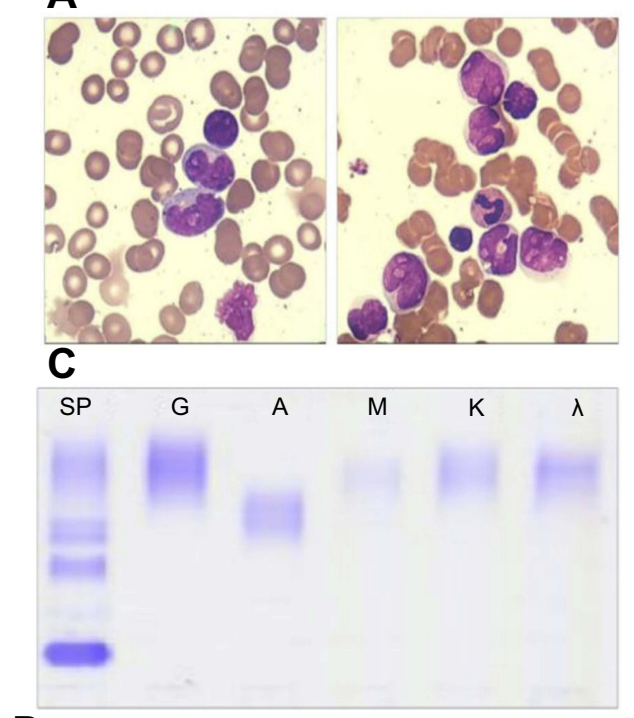

B
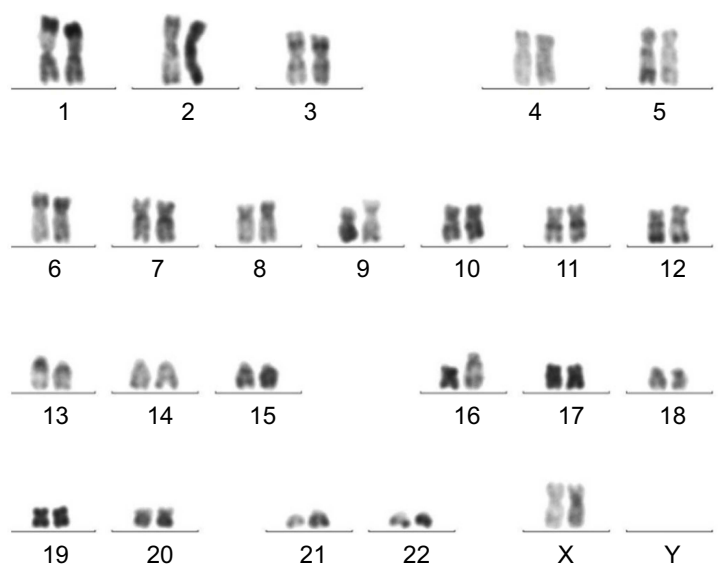

$46, X X,+1, \operatorname{der}(16) \operatorname{der}(1 ; 16)(q 10 ; p 10) t(16 ; 21)(p 11 ; q 22), \operatorname{der}(21) t(16 ; 21)(p 11 ; q 22)[20]$

D
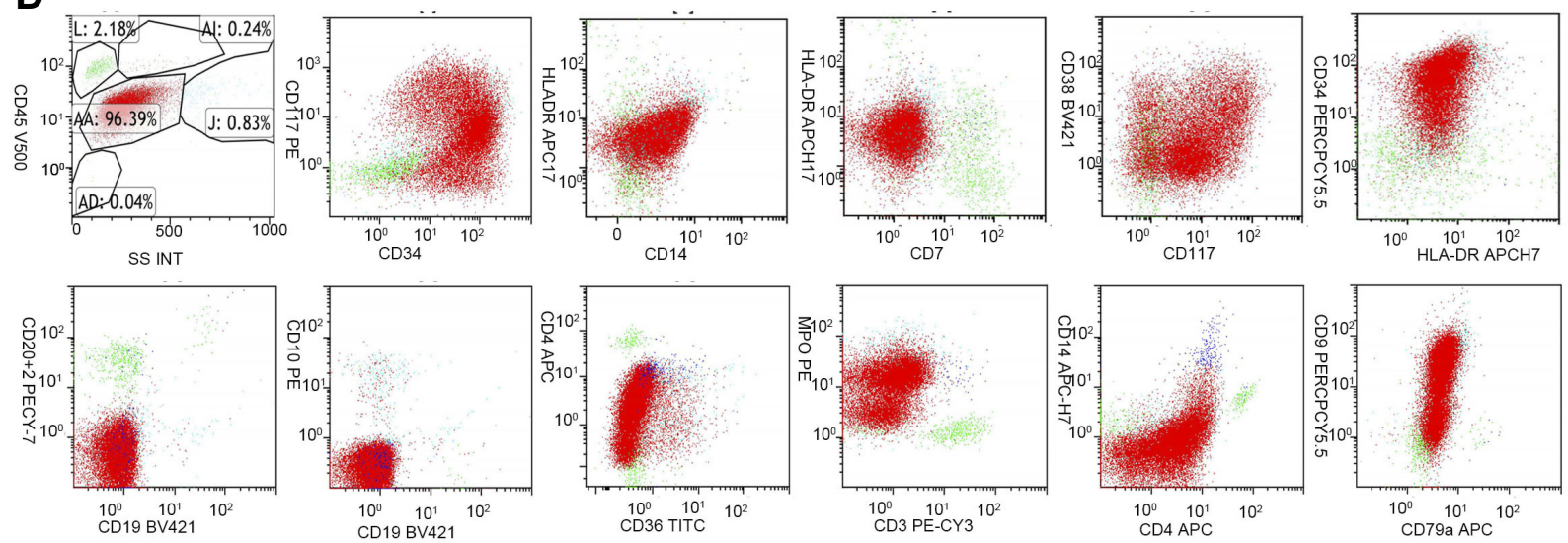

Figure I Laboratory results of this patient. (A) The morphology of bone marrow (BM). (B) The karyotype of BM cells. (C) Immunofixation electrophoresis of peripheral blood. (D) The immunophenotype of BM cells.

Table I All screened fusion gene

\begin{tabular}{|l|l|l|l|l|}
\hline I. BCR-ABL & 2. PML-RARA & 3.AMLI-ETO & 4.CBFB-MYHII & 5. MLL-AF9 \\
6. MLL-AF4 & 7. MLL-ENL & 8. MLL-AFI0 & 9. MLL-SEPT6 & 10.MLL-ELL \\
II. MLL-AFI7 & I2. MLL-AFIq & I3. MLL-AFIP & 14. MLL-AF6 & I5.NPM-RARA \\
I6.PLZF-RARA & I7.AMLI-MDSI/EVII & I8.AMLI-MTGI6 & 19.TEL-ABL & 20. TELJJAK2 \\
2I. TEL-AMLI & 22. TEL-PDGFRB & 23.E2A-PBXI & 24.E2A-HLF & 25.SIL-TALI \\
26 FIPILI-PDGFRA & 27. DEK-CAN & 28.NPM-MLFI & 29. STAT5B-RARA & 30.ETV6-PDGFRA \\
3I. NUP98-HOXAI3 & 32. UP98-HOXCII & 33. UP98-HOXDI3 & 34.NUP98-HOXA9 & 35.NUP98-HOXAII \\
36 NUP98-PMXI & 37. MLL-AFX & 38. FIPLLI-RARA & 39.PRKARIA-RARA & 40.NUMAI-RARA \\
4I. NPM-ALK & 42. SET-CAN & 43.TLS-ERG & & \\
\hline
\end{tabular}


Table 2 Next-generation DNA sequencing of bone marrow

\begin{tabular}{|c|c|c|c|c|c|}
\hline Gene & Mutation site & Nucleotide & Amino acid & DbSNP & Rate\% \\
\hline $\mathrm{BCOR}$ & Exon 12 & c.4586_4589del & p.GI529Efs*4 & - & 51.7 \\
\hline PLCGI & Intron29 & c. $3556+4 A>G$ & - & - & 49.9 \\
\hline DIS3 & Exon 14 & c. $1760 \mathrm{C}>\mathrm{T}$ & p.s587F & rs|4495754| & 48.4 \\
\hline JAK3 & Exon6 & c. $665 \mathrm{G}>\mathrm{A}$ & p.R222H & rs19986895 & 49.0 \\
\hline BRAF & Exon I & c. $64 \mathrm{G}>\mathrm{A}$ & p.D22N & rs397507456 & 51.6 \\
\hline JAK2 & Exon5 & c. $380 \mathrm{G}>\mathrm{A}$ & p.GI27D & Rs56II 8985 & 45.1 \\
\hline
\end{tabular}

$(16 ; 21)(\mathrm{p} 11 ; \mathrm{q} 22)$ (Figure 1B). Thus, next-generation DNA sequencing (NGS) technology showed that BCOR (51.7\%), PLCG1 (49.9\%), DIS3 (48.4\%), BRAF (51.6\%), JAK2 (45.1\%), JAK3 (49.0\%) were mutated in bone marrow (Table 2). Surprisingly, we found that peripheral blood immunofixation electrophoresis showed that gamma region is seen with a monoclonal light chain lambda component (Figure 1C). Laboratory examinations showed high level of LDH $3261 \mathrm{U} / \mathrm{L}$ (range 120-250 U/L), globulin $28.1 \mathrm{~g} / \mathrm{L}$ (range 20-40 g/L), albumin $37.3 \mathrm{~g} / \mathrm{L}$ (range 40-55 g/L), $\beta-\mathrm{MG} 2.08 \mathrm{mg} / \mathrm{L}$ (range 1.0-3.0 $\mathrm{mg} / \mathrm{L}$ ), calcium $2.12 \mathrm{mmol} / \mathrm{L}$ (range 2.11-2.52 mmol/L), IgM $1.61 \mathrm{~g} / \mathrm{L}$ (range 0.46-3.04 g/ $\mathrm{L}$ ), IgA $1.8 \mathrm{~g} / \mathrm{L}$ (range $0.82-4.35 \mathrm{~g} / \mathrm{L}$ ), and $\operatorname{IgG} 10.7 \mathrm{~g} / \mathrm{L}$ (range 7.51-15.60 g/L). Urine kappa light chain 13.7 $\mathrm{mg} / \mathrm{L}$ (range 0-20 $\mathrm{mg} / \mathrm{L}$ ), urine lambda light chain $<3.72 \mathrm{mg} / \mathrm{L}$ (range $0-50 \mathrm{mg} / \mathrm{L}$ ), blood kappa light chain $2.12 \mathrm{~g} / \mathrm{L}$ (range 1.70-3.70 g/L), blood lambda light chain $1.62 \mathrm{~g} / \mathrm{L}$ (range $0.9-2.1 \mathrm{~g} / \mathrm{L}$ ), creatinine: $61 \mu \mathrm{mol} / \mathrm{L}$ (range $41-73 \mu \mathrm{mol} / \mathrm{L}$ ). According to the clinical symptoms and pathological results, final diagnosis of acute monocytic leukemia, subtype M5b, with BCOR mutation and TLS-ERG expression was confirmed.

\section{Methods}

High-throughput gene sequencing was carried out by ultrahigh multiple PCR exon enrichment technology with an average sequencing depth of $800 \times$. Mutation analysis was performed by Ion Reporter System and Variant Reporter Software. Once diagnosed, the patient underwent one cycle of IA (Idarubicin $10 \mathrm{mg} \mathrm{d} 1-4$, cytarabine $0.075 \mathrm{~g}$ q12 h d1-7).

\section{Ethics statement}

This study has been approved by the Ethics Committee of the Fourth Affiliated Hospital of Zhejiang University. Before collecting clinical isolates from the patient, we informed her of our research purposes and written informed consent for participation in the study was obtained. Written informed consent for publication of the case details and clinical images was obtained from the patient.

\section{Results}

Twenty-five days after chemotherapy onset, bone marrow examination showed that primitive and immature monocytes accounted for 3\%. Chromosome analysis showed 46, XX karyotype without any cytogenetic abnormalities. Minimal residual disease: Abnormal myeloid primitive cells accounted for $0.01 \%$. Fusion gene detection showed that $T L S-E R G$ turned negative. BCOR mutation was not detected by NGS. Mutations of PLCG1, DIS3, BRAF, $J A K 2$, JAK3 still exist. The disease reached complete remission (CR). Peripheral blood immunofixation electrophoresis turned negative.

\section{Discussion}

AML is the most common malignancy in the hematologic system which mainly derives from the malignant-cloned monoclonal of the granulocyte stem cell. ${ }^{1,2}$ The pathogenesis of monoclonal immunoglobulinemia is unknown, as clones derive from plasma cells, mutations and tumors of B-generation hematopoietic precursor cells, chronic infections, connective tissue diseases, etc., can stimulate excessive proliferation of monoclonal immunoglobulins in plasma B cells. ${ }^{3}$ According to WHO 2008 diagnostic criteria, the serum monoclonal immunoglobulin (Ig) concentration in monoclonal gammopathyof undetermined significance (MGUS) patients was $<30 \mathrm{~g} / \mathrm{L}$, and the bone marrow plasma cells were $<10 \%$, and there were no lytic bone lesions, hypercalcemia, anemia or renal insufficiency associated with the proliferation of monoclonal plasma cells. Monoclonal immunoglobulinemia and AML are both clonal diseases, but originated from different clones. Clinically, hematological diseases with 
MGUS are frequent, but there are few literature reports and researches. Roeker L E observed 605 cases of MGUS and found that the risk of developing acute leukemia (ALL or AML) or myelodysplastic syndromes (MDS) was 1.83 times higher in MGUS patients than controls. ${ }^{4}$ Mailankody S also observed a higher risk for AML/MDS following MGUS (SIR 8.01, 95\% CI 5.40-11.43). ${ }^{5} \mathrm{Fei} \mathrm{Li}$ has reported two cases of MDS with high monoclonal immunoglobulin, one of which was classified as MDSRAEB-t according to the original FAB classification and AML according to the WHO classification in $2008 .{ }^{6}$ But none of them elucidated the underlying biological mechanisms. According to WHO 2008 diagnostic criteria, this case was diagnosed as MGUS. In this case, through NGS, it was found that AML patients with MGUS may have abnormal-mutated genes, which may provide a little clue.

Genetic changes are a danger for clonal diseases. With the application of next-generation sequencing in leukemia, more and more genes are being discovered. In this case, AML patients with MGUS, by comparing CR before and after we found that while the patient's $M$ protein turned negative, the TLS-ERG fusion gene and $B C O R$ gene mutation also disappeared. The TLS-ERG fusion gene is formed by the rearrangement of $T L S$ and $E R G$ genes on chromosomes 16 and 21. The TLS-ERG leukemia fusion protein inhibits E1A premRNA splicing. ${ }^{7}$ The current study holds that the expression of this fusion gene indicates rapid disease progression and poor prognosis. ${ }^{8}$ BCOR mutations can be found in AML, chronic myelomonocytic leukemia (CMML), MDS, aplastic anemia, and often coincide with DNMT3 gene mutations, suggesting that it may affect the occurrence of leukemia through epigenetics. ${ }^{9}$ Through whole-exome Sequencing, some scholars found that BCOR mutations in AML with normal karyotype (3.8\%), in AML without NPM1, CEBPA, FLT3-ITD, or IDH1 and MLL-PTD mutations (17.1\%), in with DNMT3A mutated $(43.5 \%) .{ }^{10}$ Frederik Damm also found that $B C O R$ mutations in MDS (4.2\%) and CMML (7.4\%). ${ }^{11}$ The BCOR gene is located on p11.4 of chromosome $\mathrm{X}$ and encodes an ubiquitously expressed nuclear protein. ${ }^{12}$ BCOR mutations are often coincided with other genes, and $B C O R$ mutations are associated with poor prognosis. ${ }^{11} B C O R$ is a newly discovered corepressor of BCL-6, which can play a supporting role when $B C O R$ combines with DNA; when $B C O R$ is overexpressed, it can enhance the inhibition of BCL-6. BCL-6 is highly expressed in tumor cells, ${ }^{13,14}$ it encodes transcriptional repressors which are required for the formation of the germinal center and may affect apoptosis. ${ }^{15}$ Bcl-6 inhibits the differentiation of germinal center B cells into plasma cells.

\section{Conclusion}

Patients with $T L S-E R G$ fusion gene which is a poor prognosis gene. AML with monoclonal antibody also indicates a poor prognosis. BCOR abnormal expression may increase the inhibitory effect of BCL-6 and affect the apoptosis of $\mathrm{B}$ cells, and $\mathrm{B}$ cells continue to secrete immunoglobulin. BCOR may affect plasma cell function. Indicating that monoclonal immunoglobulinemia may have relationships with $B C O R$ mutation. However, little studies have focused on the $B C O R$ gene mutation site up to now. Whether the BCOR gene mutation results in the combination of the AML and MGUS requires further investigation.

\section{Acknowledgments}

The research was supported by fundings of the Science and Technology Department of Zhejiang Province, China (2016C33160), the Public Technology Research Projects of Yiwu, China (2016-S-05), and the Key Medical Discipline of Yiwu, China (Hematology, 2018-2020).

\section{Disclosure}

The authors report no conflicts of interest in this work.

\section{References}

1. Passegué E, Jamieson CH, Ailles LE, Weissman IL. Normal and leukemic hematopoiesis: are leukemias a stem cell disorder or a reacquisition of stem cell characteristics? Proc Natl Acad Sci U S A. 2003;100(Suppl 1):11842-11849. doi:10.1073/pnas.2034201100

2. Hope KJ, Jin L, Dick JE. Acute myeloid leukemia originates from a hierarchy of leukemic stem cell classes that differ in self-renewal capacity. Nat Immunol. 2004;5(7):738-743. doi:10.1038/ni1080

3. Bida JP, Kyle RA, Therneau TM, et al. Disease associations with monoclonal gammopathy of undetermined significance: a populationbased study of 17,398 patients. Mayo Clin Proc. 2009;84(8):685-693. doi:10.1016/S0025-6196(11)60518-1

4. Roeker LE, Larson DR, Kyle RA, et al. Risk of acute leukemia and myelodysplastic syndromes in patients with monoclonal gammopathy of undetermined significance (MGUS): a population-based study of 17,315 patients. Leukemia. 2013;27(6):1391-1393. doi:10.1038/leu.20 13.34

5. Mailankody S, Pfeiffer RM, Kristinsson SY, et al. Risk of acute myeloid leukemia and myelodysplastic syndromes after multiple myeloma and its precursor disease (MGUS). Blood. 2011;118(15):40864092. doi:10.1182/blood-2011-05-355743

6. Fei L, Hai-Yan Z. A report of two cases of myelodysplastic syndrome with increased monoclonal immunoglobulin. J Clin Exp Med. 2011,10 (10):735-736. doi:10.3969/j.issn.1671-4695.2011.10.008 
7. Yang L, Embree LJ, Hickstein DD. TLS-ERG leukemia fusion protein inhibits RNA splicing mediated by serine-arginine proteins. Mol Cell Biol. 2000;20(10):3345-3354. doi:10.1128/MCB.20.10.3345-3354.2000

8. Zhang Z, Zou J, Yuantang LI, et al. Clinical characteristics and laboratory analyses of acute myeloid leukemia with $\mathrm{t}(16 ; 21)(\mathrm{p} 11$; q22). Oncol Lett. 2015;9(5):2244-2248. doi:10.3892/ol.2015.3051

9. Fan Z, Yamaza T, Lee JS, et al. BCOR regulates mesenchymal stem cell function by epigenetic mechanisms. Nat Cell Biol. 2009;11 (8):1002. doi: $10.1038 /$ ncb 1826

10. Damm F, Chesnais V, Nagata Y, et al. BCOR and BCORL1 mutations in myelodysplastic syndromes and related disorders. Blood. 2013;122 (18):3169-3177. doi:10.1182/blood-2012-11-469619

11. Grossmann V, Tiacci E, Holmes AB, et al. Whole-exome sequencing identifies somatic mutations of BCOR in acute myeloid leukemia with normal karyotype. Blood. 2011;118(23):6153-6163. doi:10.118 2/blood-2011-07-365320
12. Wamstad JA, Bardwell VJ. Characterization of Bcor expression in mouse development. Gene Expr Patterns. 2007;7(5):550-557. doi:10. 1016/j.modgep.2007.01.006

13. Ye BH, Lista F, Lo Coco F, et al. Alterations of a zinc fingerencoding gene, BCL-6, in diffuse largecell lymphoma. Science. 1993;262(5134):747-750. doi:10.1126/science.8235596

14. Ye BH, Cattoretti G, Shen Q, et al. The BCL-6 proto-oncogene controls germinal-centre formation and Th2-type inflammation. Nat Genet. 1997;16(2):161-170. doi:10.1038/ng0697-161

15. Huynh KD, Fischle W, Verdin E, Bardwell VJ. BCOR, a novel corepressor involved in BCL-6 repression. Genes Dev. 2000;14 (14):1810-1823.

\section{Publish your work in this journal}

OncoTargets and Therapy is an international, peer-reviewed, open access journal focusing on the pathological basis of all cancers, potential targets for therapy and treatment protocols employed to improve the management of cancer patients. The journal also focuses on the impact of management programs and new therapeutic

Submit your manuscript here: https://www.dovepress.com/oncotargets-and-therapy-journ agents and protocols on patient perspectives such as quality of life, adherence and satisfaction. The manuscript management system is completely online and includes a very quick and fair peer-review system, which is all easy to use. Visit http://www.dovepress.com/ testimonials.php to read real quotes from published authors. 